\title{
PEMANFAATAN KULIT NENAS (Ananas comosus) SEBAGAI MEDIA PERTUMBUHAN MAGGOT (Hermetia illucens)
}

\author{
(The Utilization Of Pineapple Rind (Anana comosus) As A Medium Maggot \\ (Hermetia illucens) Growth)
}

\author{
Tania Serezova Augusta, Yusanti Mantuh, Deby Setyani \\ Fakultas Perikanan Universitas Kristen Palangka Raya \\ Jalan RTA. Milono Km. 8,5 Palangka Raya \\ Penulis koresponden : taniaserezova@ gmail.com
}

Article Submitted: 09-07-2021

Article Accepted: 05-08-2021

\begin{abstract}
Feed is a source of energy for the growth life of living things, and the important substance is protein.Therefore, there is need for alternative raw materials to replace fish meal and local prioritized that are always available. Maggot is a living things that comes from the eggs of the Black Soldier Fly(Hermetia illucens). This type of fly is easy to breed. Black Soldier Fly (BSF) eggs will hatch into larvae or commonly referred to as maggots and maggot larvae like the distinctive scent of the media.This study was to determine the utilization of Pineapple rind(Ananas comosus)with different compositions as a medium for maggot (Hermetia illucens) growth, in an attempt reducing the problem high cost of feed and as use of organic waste as a medium maggot growth. The research management that be used descriptive method, a method are to provide a systematic, factual and accurate description data on the growth of maggots using pineapple rind as a medium. The method of out research activities using a Completely Randomized Design used consisted of 3 treatment stages with 3 replications each, so that the number of experimental units was 9 replications. The analysis of variance ANOVA on the total weight of maggot growth shows that $\mathrm{F}_{\text {count }}=11,85 \%>\mathrm{F}_{\text {tabel0,01\% }}=10,92 \%$ shows a very significant difference. The decision taken to accept $\mathrm{H}_{1}$ and reject $\mathrm{H}_{0}$ which means the growth of maggots with different compositions has very significant effect on the growth of maggots. The result showed that pineapple rind could be used as a medium for maggot growth with the addition of bran and molasses with a ratio of $15 \mathrm{~kg}$ pineapple rind, $5 \mathrm{~kg}$ bran and $50 \mathrm{~m} 1 / 5$ bottle cap.
\end{abstract}

Kata Kunci :Feed, black soldier fly, maggot, pineapple rind, growth

\section{PENDAHULUAN}

Salah satu komponen penentu keberhasilan budidaya ikan adalah pakan. Mahalnya harga pakan pabrik merupakan permasalahan yang umum dihadapi dalam usaha budidaya ikan yaitu bisa mencapai 60$70 \%$ dari alokasi biaya produksi. Salah satu cara untuk menekan biaya produksi tersebut adalah menggunakan pakan yang dibuat daribahan lokal yang relatif murah sehingga dapat memberikan keuntungan ganda (Afrianto dan Liviawati, 2005).

Permasalahan sampah di Indonesia salah satunya adalah meningkatnya volume limbah sampah organik yang mudah membusuk berupa sampah sisa makanan (food waste)yang dibuang dari berbagai tempat,baik itu limbah rumah tangga, restoran, usaha kuliner dan pabrik pengolahan makanan (Kiran dkk, 2014). Salah satu upaya yang dapat dilakukan 
adalah dengan mengolah sampah organik untuk dapat dalam usaha peternakan dan perikanan, terutama pemanfaatan limbah sayuran dan buah-buahan sebagai media pertumbuhan untuk maggot agar dapat berkembang biak dengan baik dan nantinya dapat dijadikan pakan untuk ikan budidaya yang mempunyai nilai ekonomis tinggi dan menguntungkan.

Maggot dihasilkan dari larva Black Soldier Fly-BSF Hermetia illucens atau lalat tentara hitam yang mudah untuk dikembangbiakan. Lalat BSF mempunyai panjang antara 15-20 mm, berwarna hitam, bagian dasar perutnya transparan (wasp waist) yang menyerupai lebah dan dapat hidup 5-8 hari. Setelah dewasa, BSF tidak memerlukan makan, karena lalat dewasa sepanjang hidupnya akan kawin dan bereproduksi.Pada fase perkembangan dari pupa, sayap lalat dewasa dalam keadaan terlipat, kemudian mulai terbuka sempurna hingga menutupi antara kepala dan abdomen (torak). Lalat jantan mempunyai umur yang lebih lama dari lalat betina (Tomberlin dkk, 2002).

Maggot BSF ini dapat dijadikan alternatif pakan yang mempunyai kandungan protein cukup tinggi.Maggot BSF tidak berbau seperti pakan komersial pada umumnya, mudah dicerna oleh ikan dan dapat diolah menjadi tepung sebagai penganti tepung ikan dalam pembuatan pakan. Selain itu maggot pun dapat diberikan sebagai pakan ikan secara langsung dalam bentuk segar ataupun dibuat menjadi pelet dengan tambahan campuran dedak. Dengan tambanan penggunaan maggot selain pakan komersil, dapat menekan biaya produksi dalam budidaya ikan.

Penelitian ini bertujuan untuk mengetahui pemanfaatan kulit buah nanas sebagai media pertumbuhan maggot BSF. Manfaat dari kegiatan ini adalah dapat dijadikan sebagai sumber informasi bagi masyarakat dalam pemanfaatan kulit buah nanas sebagai media pertumbuhan maggot
BSF sehingga dapat diterapkan di masyarakat, mengurangi permasalahan tentang pakan yang memerlukan biaya yang tinggi serta pemanfaatan limbah organik untuk media pertumbuhan maggot BSF yang berprotein tinggi, murah dan mudah dikembangkan sebagai pakan alternatif ikan.

\section{METODE PENELITIAN}

\section{Waktu dan Tempat}

Penelitian ini dilaksanakan 2 (dua) bulan, dari bulan April - Mei 2021 di Rumah Pembuatan Pakan Ikan Fakultas Perikanan UniversitasKristen Palangka Raya Kalimantan Tengah.

\section{Alat danBahan}

Alat yang digunakan timbangan manual kapasitas $5 \mathrm{Kg}$, timbangan digital, toples, Ember/baskom, bak kayu, plastik transfaran, mistar, alat tulis, termometer, waring, kameradan sarung tangan karet. Sedangkan bahan berupa kulit nanas, dedak padi, molase dan telur maggot BSF 10 gram.

\section{Prosedur Pene litian}

1. Penelitian ini menggunakanRAL (Rancangan Acak Lengkap) dengan 9 satuan percobaan (3 perlakuan dan 3 ulangan, yaitu : Perlakuan A : Kulit nanas $15 \mathrm{~kg}$ dan molase $50 \mathrm{ml} / 5$ tutup botol; Perlakuan B : Kulit nanas $15 \mathrm{~kg}$, dedak $5 \mathrm{~kg}$ dan molase $50 \mathrm{ml} / 5$ tutup botol; Perlakuan C : Kulit nanas $15 \mathrm{~kg}$ dan dedak $5 \mathrm{~kg}$.

2. Persiapan Lokasi.

3. Persiapan Wadah Budidaya Maggot menggunakan bak yang terbuat dari papan berukuran $45 \times 70 \mathrm{~cm}$ berjumlah 9 buah yang telah dilapisi dengan plastik bening.

4. Persiapan Bahan Untuk Media Pertumbuhan Maggot;

Cara pembuatan media budidaya maggot adalah sebagai berikut :

1. Kulit buah nanas ditimbang dan dicincang secara manual hingga kecil.

2. Setelah dicincang kulit buah nanas dicampurkan dengan masing-masing 
komposisi sesuai perlakuan A, B dan Cdengan 3 kali ulangan, lalu media dimasukan kedalam ember/baskom dan ditutup rapat. Media difermentasi selama 1 minggu.

3. Kemudian telur maggot BSF dimasukan kedalam bak/baskom untuk ditetaskan, setelah telur maggot menetas lalu larva maggot dipindahkan kedalam masingmasing bak dengan berat 1 gram/bak. Media diaplikasikan ke maggot BSF setiap hari dengan cara menimbang media pada hari pertama 100 gr, hari kedua 200 gr hingga seterusnya dan bak ditutup menggunakan waring dengan rapat.

4. Panen Maggot

Pada tahapan ini telur/cluster akan menetas dalam waktu 3-4 hari, bayi larva yang baru menetas memiliki ukuran kurang dari $1 \mathrm{~mm}$, setelah 1-2 minggu maggot BSF akan menjadi larva dewasa dengan warna kecoklatan, pada hari yang ke 21 warna maggot akan berubah menjadi berwarna hitam yang dinamakan dengan fase prepupa, dan setelah 1 bulan pupa akan menetas menjadi lalat tentara hitam. Cara pemanenan maggot dilakukan secara manual yaitu maggot BSF diambil dan dipisahkan dari media budidaya dan disimpan ke wadah yang sudah disiapkan.

\section{Parameter Pengamatan}

$\begin{array}{rcr}\text { Parameter yang diamati } & \text { selama } \\ \text { penelitian yaitu suhu media untuk }\end{array}$ pertumbuhan maggot BSF menggunakan termometer, lama pertumbuhan maggot BSF, mengukur panjang rata-rata maggot BSF, menimbang berat maggot BSF sebanyak 100 ekor, mengukur berat total maggot BSF saat panen dari masing-masing bak, dan uji proksimat tepung maggot untuk melihat kandungan protein, lemak, dan kadar air dari perlakuan yang berbeda. Uji proksimat hanya menggunakan maggot BSF tanpa dicampur dengan bahan lainnya dengan cara maggot BSF dioven atau dijemur dibawah sinar matahari lalu setelah maggot menjadi kering maggot $\mathrm{BSF}$ dihaluskan menggunakan blender hingga berbentuk tepung. Dalam penelitian Aam (2012) mendapatkan bahwa rataan kadar bahan kering maggot Hermetia illucens yang tumbuh dimedia bungkil kelapa yaitu 37.67 gram dan yang menggunakan media bungkil kelapa sawit yaitu 37,94 gram.

\section{Analisis Data}

Untuk mengetahui adanya pengaruh perlakuan yang diberikan pada pertumbuhan dan kelangsungan hidup maggot,data yang diperoleh dianalisi secara RAL menggunakan Analisi Sidik Ragam (Steel dan Torrie , 1991). Apabila ada pengaruh terhadap perlakuan selanjutnya diuji menggunakan Beda Nyata Terkecil (BNT) pada taraf 1\%. (Mobilestatistik , 2021)

\section{HASIL DAN PEMBAHASAN}

\section{Suhu Pada Media}

Untuk dapat tumbuh optimal, larva BSF memerlukan suhu sekitar $29,3^{\circ} \mathrm{C}$ dan tersebar pada $40^{\circ} \mathrm{LU}$ - $45^{\circ} \mathrm{LS}$ (Leclercq, 1997). Hasil penelitian Rachmawati dkk (2010), menyatakan bahwa larva dan pupa BSF yang dipelihara pada suhu $27^{\circ} \mathrm{C}$ berkembang lebih lama 4 hari dibandingkan jika dipelihara pada suhu $30^{\circ} \mathrm{C}$, sedangkan pada suhu $36^{\circ} \mathrm{C}$ maka pupa akan mati.

Tabel 1. Suhu Media pada Maggot BSF

\begin{tabular}{ccc}
\hline \multirow{2}{*}{ Perlakuan } & \multicolumn{2}{c}{ Suhu Rata-Rata } \\
\cline { 2 - 3 } & $\begin{array}{c}\text { Senin, } \\
10 / 5 / 2021\end{array}$ & $\begin{array}{c}\text { Sabtu, } \\
15 / 5 / 2021\end{array}$ \\
\hline $\mathrm{A}$ & $35,1^{\circ} \mathrm{C}$ & $32.4^{\circ} \mathrm{C}$ \\
$\mathrm{B}$ & $41,8^{\circ} \mathrm{C}$ & $34.0^{\circ} \mathrm{C}$ \\
$\mathrm{C}$ & $40.9^{\circ} \mathrm{C}$ & $32.2^{\circ} \mathrm{C}$ \\
\hline
\end{tabular}

Saat pengukuran pertama pada perlakuan B terdapat suhu yang cukup tinggi, diikuti dengan perlakuan $\mathrm{C}$ dan suhu terendah adalah pada perlakuan A. Sedangkan suhu pada media penelitian kurang dari $45^{\circ} \mathrm{C}$ maka tidak mempengaruhi pertumbuhan maggot BSF dan pada saat pengukuran kedua terjadi penurunan suhu 
media pertumbuhan. Hal ini dikarenakan perlakuan B mempunyai komposisi media berupa kulit nanas, dedak, dan molase, perlakuan $\mathrm{C}$ menggunakan kulit nanas dan dedak dan perlakuan A yang hanya menggunakan komposisi kulit nanas dan molase. Popa dan Green (2012) menyatakan suhu optimum pertumbuhan BSF adalah $30^{\circ} \mathrm{C}-36^{\circ} \mathrm{C}$, sedangkan pada suhu kurang dari $7^{\circ} \mathrm{C}$ dan suhu lebih dari $45^{\circ} \mathrm{C}$, larva maggot BSF akan mati.

Walaupun suhu pada media untuk pertumbuhan maggot cukup tinggi, maggot BSF tetap dapat tumbuh dengan baik karena media yang diberikan memiliki nutrisi yang tinggi sehingga tidak menghambat pertumbuhan maggot BSF.

\section{Hasil Pengamatan Pertumbuhan Maggot BSF}

Siklus hidup BSF antara 40-43 hari mulai dari telur sampai lalat dewasa, tetapi dipengaruhi oleh kondisi lingkungan dan sumber pakan yang diberikan. Pada saat bertelur, lalat betina tidak akan menempatkan telur secara langsung diatas sumber pakan dan tidak mudah terusik saat bertelur. Sebagai tempat bertelurnya, lalat betina akan meletakkan telurnya pada daun pisang kering atau potongan kardus yang berongga (Tomberlin dkk, 2009). Ada 5 stadia siklus hidup lalat BSF yaitu fase dewasa, telur, prepupa, dan pupa. Di stadia prepupa yang dapat dimanfaatkan sebagai pakan ikan (Newton, 2005).

\section{Panjang Rata-rata Maggot BSF dan Berat 100 ekor Maggot BSF}

Berdasarkan hasil pengamatan selama tujuh hari setelah diberikan media dengan komposisi yang berbeda maka diperoleh rata-rata panjang maggot $\mathrm{BSF}$ perlakuan $\mathrm{A}=1,57 \mathrm{~cm}, \mathrm{~B}=1,58 \mathrm{~cm}, \mathrm{C}=$ $1,57 \mathrm{~cm}$ dan rata-rata berat dari 100 ekor/bak maggot $\mathrm{BSF}$ pada perlakuan $\mathrm{A}=0,25 \mathrm{gr}, \mathrm{B}$ $=0,33$ gr dan $\mathrm{C}=0,25$ gr.

\section{Berat Pertumbuhan Maggot BSF}

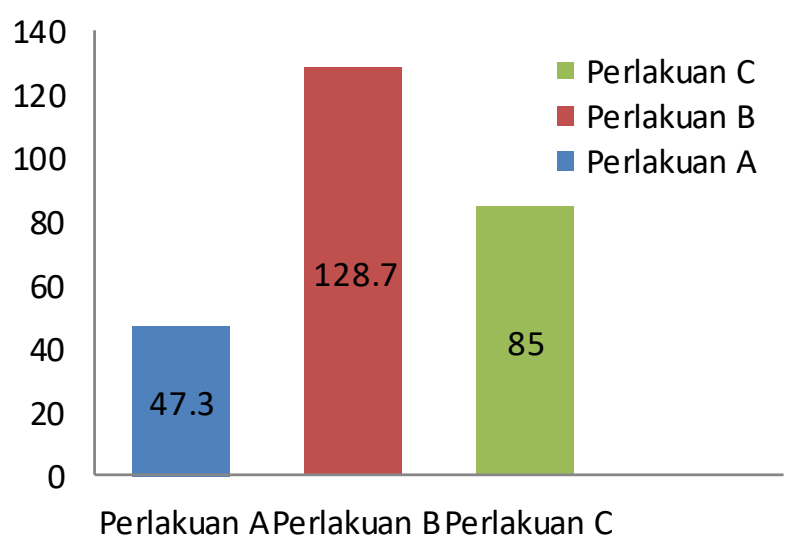

Gambar 1. Diagram rata-rata berat maggot BSF

Pertumbuhan rata-rata berat maggot $\mathrm{BSF}$ pada perlakuan $\mathrm{A}=47,3$ gr perlakuan $\mathrm{B}=128,7$ gr dan pada perlakuan $\mathrm{C}=85 \mathrm{gr}$. Pada perlakuan $\mathrm{B}$ memiliki berat rata-rata lebih tinggi dari perlakuan $\mathrm{A}$ dan $\mathrm{C}$, hal ini dikerenakan pada perlakuan B memilikikomposisi yaitu kulit nanas $15 \mathrm{~kg}$, dedak $5 \mathrm{~kg}$, dan molase $50 \mathrm{ml}$. Pada perlakuan A memiliki komposisi kulit nanas $15 \mathrm{~kg}$ dan molase $50 \mathrm{ml}$. Sedangkan perlakuan $\mathrm{C}$ kulit nanas $15 \mathrm{~kg}$ dan dedak 5 $\mathrm{kg}$.

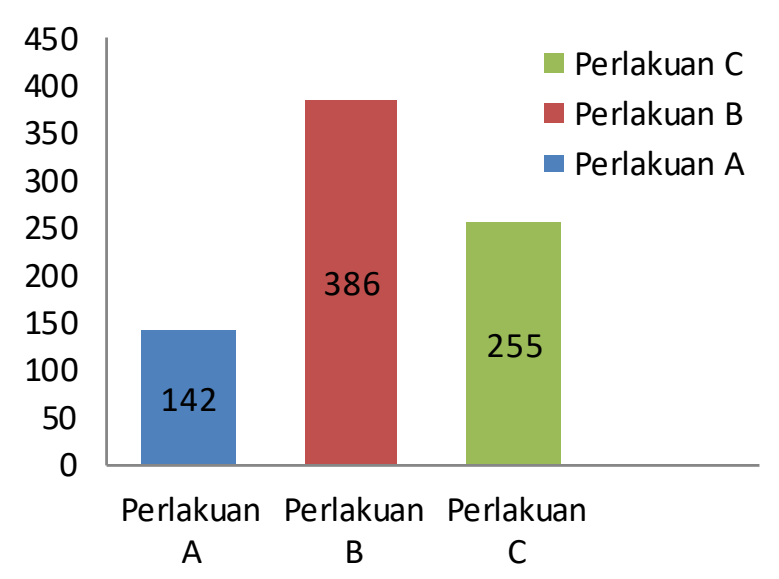

Gambar 2. Gambar diagram berat total pertumbuhan maggot BSF

Berat total pertumbuhan maggot BSF pada perlakuan $\mathrm{A}=142 \mathrm{gr}, \mathrm{B}=386 \mathrm{gr}$ dan $\mathrm{C}=255$ gr. Pada perlakuan B memiliki berat lebih tinggi dari perlakuan $\mathrm{A}$ dan $\mathrm{C}$, hal ini 
dikarenakan pada perlakuan B memiliki komposisi yaitu kulit nanas $15 \mathrm{~kg}$, dedak 5 $\mathrm{kg}$, dan molase $50 \mathrm{ml}$. Pada perlakuan A memiliki komposisi kulit nanas $15 \mathrm{~kg}$ dan molase $50 \mathrm{ml}$. Sedangkan perlakuan C kulit nanas $15 \mathrm{~kg}$ dan dedak $5 \mathrm{~kg}$. Kandungan gizi yang baik dari kulit nenas berupa lemak kasar 1,15\%, abu 3,82\%, bahan kering $88,95 \%$, protein kasar $8,78 \%$, serat kasar 17,09\%, dan BETN 66,89\% (Nurhayati, 2013). Maka dari itu kandungan nutrisi dari perlakuan $\mathrm{B}$ sangat baik bagi pertumbuhan maggot BSF karena nutrisi dari kulit nanas sangat tinggi, dicampur dengan dedak, dan molase.

Hasil ANOVA pada berat total pertumbuhan maggot BSF menunjukan bahwa $F_{\text {hitung }}=11,85 \%>F_{\text {tabel }} 0,01 \%=$ $10,92 \%$ menunjukan sangat berbeda nyata. Sehingga dapat disimpulkan komposisi media yang berbeda berpengaruh sangat nyata pada pertumbuhan maggot BSF, dimana jumlah berat rata-rata perlakuan $\mathrm{A}=$ 142 gr, $\mathrm{B}=386$ gr, dan $\mathrm{C}=255$ gr. Hal disebabkan karena perbedaan komposisi dalam media pertumbuhan maggot BSF, sehingga berpengaruh juga terhadap perkembangbiakan maggot BSF.Terlihat bahwa perlakuan $\mathrm{B}$ lebih baik dari $\mathrm{C}$, dan perlakuan $\mathrm{C}$ lebih baik dari $\mathrm{A}$.

Hasil Uji BNT pada taraf $1 \%$ diperoleh nilai sebesar 10,92\%. Hal ini menunjukkan bahwa perlakuan $\mathrm{A}, \mathrm{B}$, dan $\mathrm{C}$ menunjukkan perbedaan nyata pada setiap media. Perlakuan B menunjukkan hasil yang baik sebagai media pertumbuhan maggot dengan biomassa yang dihasilkan pada media tersebut rata-rata 128,7 gr (Gambar 1). Hal ini menunjukkan bahwa komposisi media kulit nanas, dedak dan molase sangat efektif bagi pertumbuhan maggot BSF dan memiliki kandungan gizi yang baik untuk pertumbuhan maggot BSF. Kulit nenas mengandung protein kasar $8,86 \%$, serat kasar 19,49\%, lemak kasar 1,88\%, abu $4,52 \%$, BETN $65,68 \%$ dan metabolisme energi 1995,35 kkal/kg (Ramadhan, 2016). Selain itu, dalam kulit nenas terdapat karbohidrat $17,53 \%$ dan gula reduksi 13,65\%. Menurut Murni dkk (2008) dedak mengandung nutrisi yaitu protein kasar 1214\%, kadar lemak 7-19\%, kadar abu 9-12\%, serat kasar 8-13\%, dan BETN 64-42\%. Molase memiliki kandungan protein kasar $3,1 \%$, serat kasar $60 \%$, lemak kasar $0,9 \%$ dan abu 11,9\% (Nurhilal dan Suryaningsi, 2018).

\section{Kondisi Media Untuk Pertumbuhan Maggot BSF}

Hasil pengamatan pada ketiga perlakuan dari media kulit nanas dengan komposisi yang berbeda menunjukan bahwa kondisi media memiliki kadar air yang rendah karena sebelum media diletakkan pada bak, media terlebih dahulu difermentasi untuk mengurangi kadar air dari kulit nanas, dikarenakan jika kadar air pada media terlalu tinggi maka maggot BSF akan pergi mencari tempat dengan lingkungan yang lembab, hal ini didukung oleh pernyataan Duponte (2003) bahwa maggot menyukai kondisi lingkungan yang lembab.

Kondisi dari media yang timbulnya bau yang sangat menyengat dari perlakuan $\mathrm{B}$ dan $\mathrm{C}$ karena dalam media menggunakan dedak padi sehingga membuat media menjadi bau dan dapat memancing lalat BSF dapat bertelur di media. Berbeda dengan perlakuan A yang tidak menimbulkan bau yang menyengat sehingga tidak ada lalat yang hinggap pada media.

\section{Uji Proksimat}

Hasil uji proksimat tepung maggot BSF yang dianalisis oleh Laboratorium Ilmu Nutrisi dan Makanan Ternak Universitas Lambung Mangkurat Banjarbaru maka terdapat hasil pada tabel berikut : 
Tabel 2. Hasil uji proksimat

\begin{tabular}{llccc}
\hline No & $\begin{array}{l}\text { Parameter } \\
\text { Analisis }\end{array}$ & $\begin{array}{c}\text { A } \\
(\%)\end{array}$ & $\begin{array}{c}\text { B } \\
(\%)\end{array}$ & $\begin{array}{c}\mathrm{C} \\
(\%)\end{array}$ \\
\hline 1. & kadar & 50,65 & 49,72 & 44,84 \\
& protein kasar & & & \\
2. & Kadar lemak & 17,81 & 30,74 & 33,28 \\
3. & Kadar air & 9,82 & 8,96 & 7,84 \\
\hline
\end{tabular}

Sumber: Hasil analisis laboratorium Universitas Lambung Mangkurat (2021)

Dari uji proksimat ini kita dapat mengetahui berapa persen (\%) kandungan nutrisi didalam tubuh maggot BSF yang telah dijadikan tepung dengan media kulit nanas dengan komposisi berbeda. Hasil uji proksimat tepung maggot BSF dari masingmasing perlakuan terdapat hasil kadar protein yang tinggi untuk setiap perlakuan. Menurut Rachmawati dkk (2010) kadar protein cenderung turun pada umur maggot BSF yang lebih tua. Hal ini menunjukan bahwa adanya pengaruh dari setiap media yang diberikan untuk pertumbuhan maggot BSF.

\section{KESIMPULAN}

Hasil penelitian menunjukkan bahwa kulit nenas dapat dimanfaatkan sebagai media pertumbuhan maggot dengan penambahan dedak dan molase dengan perbandingan komposisi : kulit nanas $15 \mathrm{~kg}$, dedak $5 \mathrm{~kg}$ dan molase $50 \mathrm{ml} / 5$ tutup botol.

\section{DAFTAR PUSTAKA}

Afrianto E, Liviawaty E. 2005. Pakan Ikan. Yogyakarta: Kanisius.

Aam G. 2012. Aplikasi maggot Black Soldier Fly (Hermetia illucens) yang dibiakkan dalam manur unggas sebagai campuran pakan periode pertumbuhan dan produksi telur puyuh (Coturnix coturnix japonica) disertasi, Universitas Padjadjaran Bandung.
Dellweg. 1983. Biotechnology, Vol 3, Chemie, Weinheim.

Duponte MW, Larish LB. 2003. Tropical Agriculture and Human Resources (CTAHR). Hawaii.

Kiran EU, Trzcinski AP, Ng WJ, Liu Y. 2014. Bioconversion Of Food Waste To Energy: A Review. Journal Fuel. Halaman 389-399.

Leclercq M. 1997. A propose de Hermetia illucens L (Linnaeus, 1758) ("soldier ly") (Diptera Stratiomyidae: Hermetiinae). Bull Annls Socr Belge Ent 133: 275-82.

Morales-ramos JA, RojasMG, ShapiroilanDI. 2014. Mass Production of Bene_Icial Organisms Invertebrates and Entomopathogens. Cambridge (US): Academic Press.

Mobile statistik. 2019. Ragam Uji Lanjut Dalam

Rancangan.Percobaan.https://www. mobilestatistik.com/ragam-uji-lanjutdalam-rancanganpercobaan/. Diakses 23 juni 2021.

Murni R, Akmal, Suparjo, GintingBL.2008. Pemanfaatan Limbah Sebagai Bahan Pakan Ternak 3. Laboratorium Makanan Ternak, Fakultas Peternakan, Universitas Jambi.

Newton L, Sheppard C, Watson DW, Burtle G, Dove R. 2005. Using the Black Soldier Fly, Hermetia illucens, as a Value- Added Tool For The Management Of Swine Manure. Report for The Animal and Poultry waste Management Center. North Carolina. North Carolina State University Raleigh.

Nurhayati.2013. Penampilan Ayam Pedaging Yang Mengkonsumsi 
Pakan Mengandung Tepung Kulit Nanas Disuplementasi Dengan Yoghurt.Agripet Vol 13, No. 2.

Popa R, Green T. 2012. Biology And Ecology Of The Black Soldier Fly. Amsterdam (NL): DipTerra LCC e-Book.

Rachmawati, Buchori D, Hidayat P, Hem S, Fahmi MR. 2010. Perkembangan dan Kandungan Nutrisi Larva Hermetia illucens (Linnaeus) (Diptera: Stratiomyidae) pada Bungkil Kelapa Sawit. JEI 7 (1) : 28-41.

Sianipar J, KrisnanR, Simanihuruk K, BatubaraLP 2006. Evaluasi Tiga Jenis Limbah Pertanian Sebagai Pakan Kambing Potong. Seminar nasional Teknologi Peternakan Dan Veteriner.
Steel, Torrie. 1991. Metodologi Perikanan. Gramedia. Jakarta.

Tomberlin JK, Adler PH, Myers HM. 2009. Development of the Black Soldier Fly (Diptera: Stratiomyidae) in Relation to Temperature. Enviromental Entomo. 38 : 930934.

Tomberlin JK, Sheppard DC, Joyce JA. 2002. Selected Lifehistory Traits Of Black Soldier_Lies (Diptera: Stratiomyidae) Reared on Three Arti_icial Diets. Annals Entomol Soc Amer 95 (3) : 379-86. 